\title{
Czesław Świnarski
}

\section{Rekurs w świetle "Norm Specjalnych" Sygnatury Apostolskiej : (kwestie wybrane)}

Prawo Kanoniczne : kwartalnik prawno-historyczny 15/3-4, 125-134

1972

Artykuł został zdigitalizowany i opracowany do udostępnienia w internecie przez Muzeum Historii Polski w ramach prac podejmowanych na rzecz zapewnienia otwartego, powszechnego i trwałego dostępu do polskiego dorobku naukowego i kulturalnego. Artykuł jest umieszczony w kolekcji cyfrowej bazhum.muzhp.pl, gromadzącej zawartość polskich czasopism humanistycznych i społecznych.

Tekst jest udostępniony do wykorzystania w ramach dozwolonego użytku. 
KS. CZESEAW SWINIARSKI

\section{REKURS W SWIETLE ,NORM SPECJALNYCH” SYGNATURY APOSTOLSKIEJ \\ (Kwestie wybrane)}

Treśc: - 1. Kontrola sądowa administracji kościelnej jako postulat zasady legalności $w$ kanonìcznym procesie administracyjnym. - 2. Rekurs w postępowaniu sądowo-administracyjnym. - 3. Przedmiot rekursu. - 4. Motywy rekursu. - 5. Legitymacja do wniesienia rekursu. Zakończenie.

\section{Kontrola sądowa administracji kościelnej jako postulat zasady legalności w kanonicznym procesie administracyjnym}

Ochrona prawna osób fizycznych i moralnych należy do zasadniczych funkcji władzy i systemu prawnego każdego organizmu społecznego. Nowe spojrzenie na Kościóí, zwłaszcza w relacjach pomięazy Kier ownictwem Kościoła, a Laikatem zachęciło do postulowania daleko idącej osłony praw subiektywnych 1. Prawo kościelne ma bowiem nie tylko służyć wykonywaniu władzy, ale ma również za zadanie ochraniać elementarne prawa osób.

Władza w swej służbie publicznej, a zwłaszcza w działaniu administracji, której włașciwe wykonanie zależy od ludzi, mimo faktu istnienia prawa nie zabezpiecza jednostki przed bezprawiem, nie uniemożliwia organom administracyjnym popełniania czynów niezgodnych $z$ przepisami, naruszających autonomie jednostek. Przyczyną tego są urzędnicy, którzy podobnie jak inni ludzie popelniają błędy, zdarzają się niedbali, samowolni, ulegają wpływom, wskutek czego zachodza wypadki naruszania prawa, w czasie pełnienia ich funkcji. Genezą i siłą napędową prawa administracyjnego wprowadzającą ład, porządek i praworządność jest sądowa kontrola nad administracją. Tylko organ o charakterze sądowym może zapewnić należycı całkowitą równowage między interesami publicznymi, a uprawnionymi intéresami jednostek zabezpieczając odpowiednio ich prawa podmiotowe. Nie wystarcza bowiem ani wewnętrzna

1 Paul Wir th, Erwägungen zur Neuordnung der Apostolischen Signatur, s. 660, Ius Sacrum - Festgabe für Klaus Mörsdorf zum sechzigsten Geburtstag, München 1969; Principia quae Codicis Iuris Canonici recognitionen dirigant, Typ. Pol. Vaticanis, 1967, n. 7, s. 13; Communicationes $2 / 69$, s. 83 . 
hierarchiczna kontrola administracyjna, ani bezwzględny obowiązek przestrzegania przez urzędników zasady legalności. Wszyscy urzędnicy niezależnie od swego uszeregowania hierarchicznego i rozmieszczenia $\mathrm{w}$ różnych władzach (dykasteriach), stanowią pewien zwarty korpus ożywiony duchem solidarności. To poczucie solidarnuse: sprawia, że wyższa wladza rozstrzygając spory administracyjne w jakiś sposób sądzi we wlasnej sprawie, w której jest. zainteresowana i trudno jej zdobyc się na obiektywność. Tymczasem wiemy, że „nemo iudex in causa sua". Dlatego pelną ochronę. prawną może dać tylko jednostka organizacyjna nie włączona. w hierarchię administracyjną, występująca jako ktoś trzeci ${ }^{2}$.

Potrzeba wprowadzenia zasady legalności do kościelnego postępowania administracyjnego natrafiała na zrozumiałe przeszkody zewzględu na boską konstytucję Kościoła, która nile zezwalała na. przyjęcie trójpodziału władz według wzorów ustawodawstwa państwowego. Znaleziono jednak wyjście z tej sytuacji stosując zasadę. legalności $\mathrm{w}$ kościelnlym porząaku prawnym $\mathrm{w}$ formie ograniczonej. Postulowana zasada legalności znalazła zastosowanie w kanonicznym procesie administracyjnym w powołanej Konstytucją Apostolską Papieża Pawla VI Regimini Universae Ecclesiae nr 106: instytucji jurysdykcji administracyjnej ${ }^{3}$. Konstytucja ta została potem zaopatrzona przez Ojca św. Pawła VI w Normy Specjalne. z dnia 23 marca 1968 r., które winny być zachowane na sposób. eksperymentu w Sygnaturze Apostolskiej ${ }^{4}$.

$Z$ snwił wejścia w życie „Norm Specjalnych", osobnej sekcji przydzielono do rozpatrywania spory administracyjne. Sekcja I przejęla dotychczasowe kompetencje Trybunału Sygnatury Apostolskiej, otrzymując nadto rozszerzone uprawnienia sądowo-administracyjne (Art. 17). Natomiast w postanowieniu Art. 96 „W drugiej sekcji Sygnatura Apostolska rozpatruje:

1) spory wynikłe na tle wykonywania administracyjnej władzy kościelnej, doniesione na skutek złożenia apelacji czyli rekursur przeciwko decyzji kompetentnego Dykasterium, ilekroć wskazuje się na naruszenie prawa; 2) spory dotyczące kompetencji między Dykasteriami Stolicy Apostolskiej; 3) sprawy administracyjne przekazane przez Kongregacje Kurii Rzymskiej; 4) sprawy zlecone jej. przez Papıeza" 5.

Przez powolanie II Sekcji Trybunalu Sygnatury Apostolskiej dla ochrony przed ewentualnym naruszeniem prawa przez zarządzenia. administracyjne, w myśl Konstytucji Regimini Universae Ecclesiae

2 Fernando Della Roc ca, Problemi di giustizia amministrativa net diritto canonico, La function pastoral delos obispos, Barcelona 1967, s. 280.

3 AAS, 59 (1967) $921 \mathrm{nn}$.

4 AAS, 60 (1968), 129-196.

5 Tłumaczenie polskie Ks. E. Sztafrowski ego, Posoborowe Prawodawstwo kościelne, T. II, z. 1. 
Nr 106, administracja publiczna w Kościele poddana została kontroli sądowej. Sekrcja ta nie jest trybunałem specjalnym, ale sekcja. trybunału zwyczajnego rozpatrującą skargi administracyjne, to jest rekursy, w postępowaniu sądowo-administracyjnym. Tym samym. zostal stworzony w Sygnaturze Apostolskiej system podwójnego sądownictwa zwany belgijskim ${ }^{6}$. Ustalony Normami Specjalnymi. system i forma rekursów wprowadzają $\mathrm{w}$ postępowanie administracyjne w Kościele postulaty zasady lelgalności ?.

\section{Rekurs w postępowaniu sądowo-administracyjnym}

Kontrola nad działaniem administracji omawiana jest $\mathrm{w}$ nauce prawa administracyjnego jako system środków gwarantujących. ochronę sytuacji prawnej jednostki ${ }^{8}$. Strony odwołujące się do. wyższej instancji mają do dyspozycji w procesie kanonicznym apelację i rekurs.

W postępowaniu sądowo-administracyjnym prawo kanoniczne dopuszcza liczne rekursy przeciwko dekretom sędziego i ordynariusza, by zanewnić stronie ochrone jej praw podmiotowych ${ }^{9}$. Przy pomocy skargi administracyjnej jaką jest rekurs, można domagać: się usunięcia każdego pogwałcenia prawa, lub naruszenia interesu.

Zupelnie wyraźnie dopuszczalna była skarga administracyjna w prawie kanonicznym przed Konstytucją Regimini Ecclesiae Universae jako środek obrony praw kapłana przymusowo zwolnionego z urzędu nie będącego parafią (kan. $192 \S 2,3$ ), podobnie przy przymusowym przeniesieniu (kan. $193 \S 2$ ). Także mimo zmian wprowadzonych $w$ ' Motu Proprio Ecclesiae Sanctae prawo proboszcza dalej jest chronione. Kan 2146 daje ież ochronę w postaci rekursu w postępowaniu wobec kapłanów oskarżonych o naruszenie obowiązków stanu i urzędu. Jakkolwiek prawu kanonicznemu nie jest zupelnie obca ochrona prawna przeciwlo aktom administracyjnym (kan. 1667), to jednak jest ona $\mathrm{w}$ kodeksie bardzo ograniczona, gdyż $\mathrm{Pa}-$ pieska Komisja Interpretacji Kodeksu Prawa Kanonicznego rozstrzygnięciem z dnia 22. V. 1923 r. odrzucila możliwość sądownictwa nad zarzadzeniem ordynariusza 10.

- Arcangelo Renaudo, Considerazioni su alcuni aspetti dell ativita amministrativa canonica, Monitor Ecclesiasticus, 1968, s. 331; Procedura nowa Sygnatury Apostolskiej ma analogie $z$ procedurą stosowaną $w$ włoskich trybunałach do r. 1865 , z ograniczeniami przyjętymi z pruskiego. sądownictwa sporno-administracyjnego; Jerzy Stefan Langrod, Zarys sqdownictwa administracyjnego, s. 66 nn., Warszawa 1925.

7 P. W ir t $h, d z$. cyt., 658.

8 Franciszek Longs champs, Wspóiczesne kierunki $w$ nauce. prawa administracyjnego na Zachodzie Europy, s. 207, Ossolineum 1968.

9 Np. kanony: $162 \S 2,192 \S 3,298,345,454 \S 5,513 \S 2,696 \S 2$, $880 \S 2,970,1340 \S 3,1428 \S 3$.

10 AAS $16(1924) 251$. 
Ponieważ do czasu ogłoszenia Konstytucji Regimini Ecclesiae Universae twierdzono, że ze względu na specyficzną organizacje prawa kanonicznego nie jest możliwym w Kościele wprowadzenie sądownictwa sporno-administracyjnego ${ }^{11}$, rekurs przeciwko nadużyciom władzy kościelnej do tej pory nie był znany $w$ postępowaniu administracyjno-sądowym. W konsekwencji wszystkie rekursy przeciwko aktom administracyjnym były rozpatrywane wyłącznie przez Kongregacje Rzymskie, czyli przez ten sam rodzaj władzy chociaż w stopniu wyższym. Stosowana więc była kontrola administracyjna w toku instancji przez tak zwany rekurs hierarchiczny. W tym stanie rzeczy kanoniści domagali się pełnego wprowadzenia rekursów w praktyce kościelnego sądownictwa administracyjnego 12.

Normy Specjalne obszernie mówią o rekursach w obydwu Sekcjach. Rekursy w Sekcji Drugiej Sygnatury Apostolskiej uwzględ. niają skargi przeciw czynnościom publicznej administracji kościelnej (Art. 104-123), dotyczą spraw rozwiązania sporów na tle kompetencji między Dykasteriami Kurii Rzymskiej (Art. 124), ponadto z. zachowaniem zmodyfikowanych przepisów Art. 104 i następnych maja zastosowanie w sprawach administracyjnych i dyscyplinarnych powierzonych przez Ojca św., lub przekazanych przez Dykasteria Kurii Rzymskiej (Art. 125).

\section{Przedmiot rekursu}

\section{a) Akt administracyjny}

Aktualnie ustawodawstwo kanoniczne według $\mathrm{Nr} 106$ Knstytucji Regimini, którą realizuje Art. 96 Norm Specjalnych Sygnatury Apostolskiej, przyznaje możliwość rekrutowania do tego Trybunału w wypadku gdy decyzja administracyjna naruszyła prawo. A więc wymogiem zasadniczym, by można było wnieśc ten rekurs jest, by jego przedmiotem był akt administracyjny w sensie ścisłym, wydany przez organa publicznej administracji, albo instytucję prawa publicznego, która uczestniczy $w$ wykonaniu władzy administracyjnej własnej. Akt administracyjny będący zwylkłym, normalnym, powtarzającym się przejawem dzialalności administracji publicznej, nie posiada ustalonej prawnej definicji. Możnaby go określić jako czynność administracyjną kościelnej władzy publicznej, która tworzy normę opartą na obowiązujących powszechnie przepisach prawa. Norma ta ma charakter jednostronny i określa prawnie konkretną sytuację jednostki ${ }^{13}$.

11 A. Ranaudo, Le funzioni amministrative e giudiziarie della Chiesa dopo il Concilio Vaticano II, Monitor Ecclesiasticus 1969, s. 313.

12 Iulianus $\mathrm{Herranz}$, De principio legalitatis in exercitio potestatis ecclesiasticea, s. 234-235, Acta conventus internationalis canonistarum, Romae diebus 20-25 mai 1968 celebrati, Typ. Pol. Vat. 1970.

13 Stanislaw Kasznica, Polskie Prowo Administracyjne, pojecia 
Przepisy obecnego prawa dopuszczają zaskarżenie aktu administracyjnego za pomoca rekursu tylko wtedy, gdy stanowi on zarządzenie definitywne, a równocześnie skorzystano $\mathrm{z}$ rekursu hierarchicznego do Dykasteriów Rzymskich (Nr 106 Regimini).

Nie są przedmiotem rekursu do iI Sekcji Sygnatury Apostolskiej zarządzenia wprawdzie administracyjne, ale wydane przez organa sądowe, czy ustawodawcze, względnie organa publicznej administracji czynnej. Nie mają tu miejsca również rekursy przeciw aktom jednostek administracji publicznej dotyczącym ich własnej działalności prywatnej jak nabycie, sprzedaż, dóbr diecezjalnych, parafialnych. Jednakże będzie mógł być przyjęty rekurs przeciwko derkretowi przełożonego, który tego rodzaju akt zatwierdził. Ponieważ przedmiotem rekursu są $z$ natury rzeczy akty jednostronne, nie dotyczą rekursy umów administracyjnych. Decyzje wydane przez instyzucje nie wolecione $\mathrm{w}$ hierarchię administracyjną nie są tym rekursem skarżone 14 .

Wykluczone są spod kontroli sądowo-administracyjnej wszystkie akty administracyjne wydawane przez Papieża (kan. 1683), chyba, że ma miejsce „aperitio oris".

Niejednokrotnie jednostka doznaje naruszenia prawa na skutek przewlekłego załatwiania spraw przez administrację. Nie może się jednak posłużyć rekursem do II sekcji Sygnatury Apostolskiej, gdyż tak zwane "milczenie władzy”, nie jest decyzją. Możliwym byłoby przekazanie tego rodzaju sprawy do Sygnatury Apostolskiej drogą pośrednią poprzez Dykasteria Kurii Rzymskiej (Art. 96, 3).

b) Naruszenie prawa przez akt administracyjny

Postulowane wprowadzenie $\mathrm{w}$ porządek prawny $\mathrm{w}$ Kościele zasady legalności $15 \mathrm{w}$ administracyjnym działaniu znajduje sformułowanie w przepisie Art. 106 Konstytucji Regimini mówiącym o rozstrzyganiu sporów przez II Sekcję ,...ilekroć się stwierdza, że sam akt naruszył jakieś prawo...".

Nasuwaj ąsię trudności $\mathrm{w}$ rozumieniu znaczenia słowa „lex" 16 Rozumienie „lex" w znaczeniu ustawy kościelnej mocno zawęża kompetencje II Sekcji Sygnatury Apostolskiej. Przemawia za tym również Art. 70 i 95 Regulaminu Ogólnego Kurii Rzymskiej: „Zainteresowany ma prawo rekursu ze skutkiem dewolutywnym do

$i$ instytucje zasadnicze, Poznań 1946; Prawo Administracyjne, Jerzy Sta ros ciak, s. 215, Warszawa 1965; Wacław Daw id ow i c z, Ogólne postepowanie administracyjne, s. 20 ; A. R a na u do, dz. cyt., Monitor 1969 , s. 312.

$14 \mathrm{~A} . \mathrm{R}$ a $\mathrm{n}$ a $\mathrm{u} \mathrm{\alpha}, \mathrm{Il}$ contenzioso amministrativo canonico, Monitor Ecclesiasticus 1968, s. 555-557.

15 I. Herranz, dz. cyt., $234-5$.

16 Heribert $\mathrm{Schmitz,} \mathrm{Rechtsschutz} \mathrm{und} \mathrm{kanonisches} \mathrm{Dienstrecht,}$ Ius Sacrum, s. 755, j. w. 
drugiej sekcji Sygnatury Apostolskiej, w granicach zakreślonych w Konstytucji „Regimini Ecclesiae Universae” nr 106..." „Przeciw takie jdecyzji można wnieść rekurs ze skutkiem dewolutywnym do II Sekcji Sygnatury Apostolskiej, w granicach określonych w Konstytucji „Regimini Ecclesiae Universae”, nr 106". Podobną interpretację zawężającą dał G. Pinna, Sekretarz Komisji Odnowy Kurii Rzymskiej ${ }^{17}$.

\section{c) Interes prawny}

Jednostka w swej sytuacji prawnej wobec władzy państwowej chroniona jest przez sądy administracyjne nie tylko przed naruszeniem jej praw, ale również przed naruszeniem jej interesów prawnych.

Czy w kościelnym porządku prawnym istnieje ochrona interesut prawnego jednostki?

Przez interes prawny jednostek można rozumieć pewne sytuacje prawne subiektywne, które nie są chronione przez prawo skargą sądową we właściwym tego słowa znaczeniu, których wykonanie wydaje się być zależne od usunięcia pewnych przeszkód przez władzę administracyjną. Jednostka, której naruszono interes prawny, może przeciwko temu posłużyć się rekursem do władzy.

Ponieważ $\mathrm{w}$ obecnym prawie spór administracyjny ograniczony jest do samych aktów władzy administracyjnej kościelnej, rekurujący nie może skorzystać z ochrony prawnej przewidzianej $\mathrm{Nr} 106$. Konstytucji Regimini, ze względu na brak w danym wypadku zarządzenia władzy kościelnej $\mathbf{1 8 .}$

Natomiast nic nie stoi na przeszkodzie by w takim razie nie skorzystać z prostego rekursu administracyjnego, ale zwrócić się do Sygnatury Apostolskiej, celem otrzymania możliwości rozpatrzenia. sprawy przez S. Rotę (kan. 1603 \& 2).

Dykasteria Kurii Rzymskiej mogą także skierować kwestię o naruszenie interesu prawnego do II Sekcji Sygnatury, która w takim. wypadku będzie upoważniona do rozstrzygnięcia kwestii w każdym aspekcie (Nr 107 Regimini).

\section{Motywy rekursu}

Rekurs do II Sekcji Sygnatury Apostolskiej dopuszczalny jest. $z$ motywów legalności, to jest $z$ motywów praworządności $w$ znaczeniu formalnym, nie jest on natomiast dopuszczalny $z$ motywów merytorycznych ${ }^{19}$, to jest $\mathrm{z}$ motywów praworządności w znaczeniu

17 G. M. P in n a, Riforma delia Curia Romana, Conferenza Stampa: (18 agosto 1967), Tipogr. Poligl. Vaticana 1967, s. 14.

$18 \mathrm{~A}$. $\mathrm{R}$ a $\mathrm{n}$ a u d o, Considerazioni..., s. $328,329$.

19 A. $R$ a n a u do, Il contenzioso..., s. 553 . 
materialnym. Nie chodzi tu o merytoryczne uregulowanie stosunków prawnych między powodem, a administracją.

W nauce prawa administracyjnego jako podstawę nielegalności, czyli braku praworządności w znaczeniu formalnym wymienia się wypadki: 1) niewłaściwości organu, który wydał akt (brak kompetencji), 2) naruszenie prawa, 3) nadużycie władzy, 4) brak formy aktu. Wypadki te znane są francuskiemu postępowaniu administracyjnemu jako tzw. „recours pour excès de pouvoir", zajmując w nim miejsce pierwszoplanowe. Rekurs ten wywodzi się w prostej linii z rekursu hierarchicznego 20.

Można postawić pytanie, czy podstawa rekursu w Normach Specjalnych jest tylko naruszenie prawa, czy też $i$ inne motywy legalności jak na przykład niekompetencja, nadużycie władzy.

Za tym, że chodziłoby o wszystkie trzy podstawy rekursu zdaja się przemawiać słowa tekstu Nr 106 Konstytucji Regimini: „In his casibus videt, sive de admissione recursus, sive de illegitimitate eius". Przyjmując, że słowo ,illegitimitas" odnosi się do wszystkich trzech podstaw rekursu, ku czemu skłaniają się niektórzy autorzy, moglibyśmy mówić o przyjęciu przez ustawodawstwo kościelne systemu rekursów istniejącego w cywilnym ustawodawstwie administracyjnym pochodzenia francuskiego. Skoro jednak kwestię tę zwiążemy $z$ poprzednimi rozważaniami na temat ,lex, to raczej nie można przyjmować rozszerzonego pojęcia nielegalności. Za tego rodzaju interpretacją przemawiałoby użycie określenia „legis violatio" w Art. 96, 1 i 103, 3 Norm Specjalnych. Tak też wyjaśnia tę kwestię G. Pinna mówiąc, że nie wprowadzono rekursu w procedurze administracyjnej Kościoła w takiej rozciągłości, jak to ma miejsce $w$ niektórych państwach, ale, że jest on możliwy tylko w wypadku naruszenia prawa przez akt władzy administracyjnej 21.

\section{Legitymacja do wniesienia rekursu}

Jak w każdym postępowaniu sądowym, tak i w kościelnym postępowaniu sądowo-administracyjnym kluczowym jest pojęcie strony. Uprawnioną do wniesienia rekursu przeciw naruszeniu prawa aktem administracyjnym publicznej władzy kościelnej jest osoba fizyczna, lub moralna, która twierdzi, że naruszono jej prawo.

Roztrząsana przez autorów jest kwestia, czy uprawnionym do wniesienia rekursu do II Sekcji Sygnatury Apostolskiej jest ordy-

20 Brzeziński Waclaw, Sqdowa kontrola administracji we Francji, s. 93-905, 117, Warszawa 1965; Zbigniew Now otarski, Instytucja „Recours pour excès de pouvoir", Kraków 1947, s. 27.

21 G. P i n na, dz. cyt., s. 13-14; Ignatius Gordon, Normae spe ciales Supremi Tribunalis Signaturae Apostolicae, Editio aucta introductione, fontibus et notis, Periodica de re morali canonica liturgica, vol. 59 (1970), s. 104; A. R a n a u do, Gli atti amministrativi, s. 718 nn., Monitor Ecclesiasticus, 1968. 
nariusz, którego akt administracyjny spowodował rekurs o naruszenie prawa, stwierdzone decyzją Dykasterium Rzymskiego. I. Gordon przyznaje legitymację czynną ordynariuszowi 22, przeciwnie A. Ranaudo ${ }^{23}$, Za słusznością stanowiska A. Ranaudo zdaje się przemawiać sam tekst Nr 106 Regimini, czyniący rozróżnienie między aktem (actus) władzy administracyjnej, rodzącym spór, a decyzją (decisio) kompetentnego Dykasterium. Zwłaszcza, że pod koniec cytowanego tekstu ustawodawca nadmienia "quoties contendatur a ctum ipsum legem aliquam violasse". Jak z tego wynika, chodzi tu nie o decyzję Dykasterium, lecz o rozporządzenie administracyjne, akt rodzący spór. Przeciwko stanowisku zajmowanemu przez I. Gordona można też wysunąć przepis Art. 112 Norm Specjalnych zakładający, że rekurs do Sygnatury Apostolskiej wnosi nie władza kościelna, która wydała decyzję, lecz osoba skarżąca decyzję, dlatego powiadamia się o relzursie władzę powyższą. Zaskarżonej zaś władzy kościelnej przysluguje w toku procedury w II Sekcji rekurs przeciwstawny (Art. 112), który jest odpowiedzią na czynione zarzuty naruszenia prawa.

Nie znajdujemy w Normach S'pecjalnych odpowiedzi, czy uprawnionymi do wniesienia rekursu mogą być laicy.

Nowe rozumienie Kościoła i roli Laikatu w Kościele posoborowym stawia coraz wyraźniej wymogi daleko idącej ochrony praw osobowych wszystkich wiernych. Sobór Watykański II podkreśla, że „W epoce naszej ludzie coraz więcej uświadamiają sobie godność osoby ludzkiej", że coraz bardziej rośnie liczba tych, którzy domagają się „prawnego określenia wladzy publicznej, aby nie byla nadmiernie uszczuplona wolność osoby ludzkiej" (Deklaracja o wolności relig. 1), że „aby współpraca obywateli wykonywana ze świadomością pełnienia obowiązku w życiu codziennym państwa przynosiła pomyślne skutki potrzebny jest pozytywny porządek prawny, któryby ustalał odpowiedni podzial funkcji i organów wladzy państwowej, a równocześnie skutecznie doał o zachowanie praw bez czyjejkolwiek szkody". (Konstytucja Duszpasterska o Kościele 75).

Zatem $i$ władza publiczna $w$ Kościele $w$ swej dziak̉alności administracyjnej pojętej jako służba musi w całym zakresie przyznać $\mathrm{i}$ przestrzegać prawa osobowe wiernych $\mathrm{w}$ sferze ich autonomii zwłaszcza wobec coraz większego angażowania świeckich na różnych odcinkach życia Kościoła, mając przed oczyma słowa Konstytucji Dogmatycznej o Kościele: „Duch Swięty nie tylko przez sakramenty i posługi uświęca i prowadzi Lud Boży oraz cnotami go przyozdabia, ale 'udziela każdemu jak chce' (1 Kor. 12, 11) darów swoich, rozdziela między wiernych wszelkiego stanu także szczególne laski, przez które czyni ich zdatnymi i gotowymi do podej-

22 I. G or d o n, dz. cyt., s. 102.

$23 \mathrm{~A}$. $\mathrm{R}$ a $\mathrm{n}$ a u d o, $I l$ contenzioso..., s. 561 . 
mowania rozmaitych dziel,, lub funizcji mających na celu nowe i dalszą pożyteczną rozbudowę Kościoła" 24 .

\section{Zakończenie}

Normy Specjalne Sygnatury Apostolskiej wydane stosunkowo szybko po ogłoszeniu Konstytucji Apostolskiej Regimini Ecclelsiae Universae sa niewątpliwie kroikiem naprzód w kierunku reformy prawa kościelnego. Zabezpieczają one pelniej ochronę praw podmiotowych Ludu Bożego na odcinku gdzie wierni stykają się z działaniem administracji kościelnej, tam gdzie to co ludzkie $w$ Kościele przeszkadza czasem $\mathrm{w}$ funkcjonowaniu organizmu kościelnego.

Korzystając $\mathrm{z}$ doświadczeń ustawodawstwa cywilistycznego wprowadzono w prawo kanoniczne instytucję sądownictwa sporno-administracyjinego $\mathrm{z}$ różnymi ograniczeniami, ad experimentum. Wprawdzie ochrona praw podmiotowych zawężona zostala tylko do wypadku naruszenia prawa przez akt administracyjny, ale w rozwinięciu tego rekursu zarysowują się wytyczne co do rekursu doty-czącego rozwiązania sporów na tle kompetencji między Dykasteriami Kurii Rzymskiej (Art. 124), jak i procesów administracyjnych i dyscyplinarnych powierzonych przez Ojca sंw., lub przekazanych przez Dykasterie Kurii Rzymskiej (Art. 125).

Zainteresowane strony korzystając $z$ systemu rekursów w sporze o naruszenie prawa przez akt administracyjny, moga posługiwać się rekursem ponowionym (Art. $107 \S 2$ ), rekursem przeciwstawnym (Art. 112), r. przeciwko decyzji selrretarza (Art. 102), r. przeciw dekretom odrzucającym (Art. 1i6).

Szereg kwestii wiążących sie $z$ przedmiotem rekursu, uprawnieniami do występowania $w$ sporze sąwodo-administracyjnym, terminami, skutkami rekursu wsikazuje na luki 25, skądinąd jasno sformulowanych i przejrzystych przepisów Norm Specjalnych.

Nieprzewidzianym wypadkom Art. 126 nakazuje o ile się to da stosować przepisy proceduralne zawarte w Kodeksie Prawa Kanonicznego. Doświadczenia zebrane posłużą w redagowaniu przyszlego Kodeksu Prawa Kanonicznego, dając także wskazówki jak się ma kształtować sądownictwo administracyjne na szczeblach niższych.

\section{ZUSAMMENF ASSUNG}

\section{Der Rekursus im Lichte der "Normae Speciales Signaturae Apostolicae" (Questiones selectae)}

Die Tätigkeit der kirchlichen Verwaltung wurde einer gerichtlichen Kontrolle unterworfen, nachdem die Konstitution Regimini Universae Ecclesiae (Nr. 106) im Höchsten Tribunal der Apostolischen Signatur

24 Lumen gentium, n. 12.

25 I. Gordon, dz. cyt., s. 105; H. S chmitz, dz. cyt., s. 756. 
eine zwiete Sektion errichtet hat, deren Aufgabe es ist, Gerichtsschutz gegen etwaige Verletzungen des Rechtes durch Verwaltungsakte zu gewären. Durch die Normae Speciales Signature Apostolicae vom 23. März 1963. wurden in das verwaltungsgerichtliche Verfahren das System und die Form der Rekurse eingeführt und dadurch wurde das Postulat der Legalität mit gewissen Einschränkungen realisiert.

Gegenstand eines Rekurses an die zweite Sektion der Apostolischen Signatur kann lediglich ein Verwaltungsakt sein, der ein Recht verletzt, dabei eine definitive Verordnung darstellt, und auch das erst, nachdem der hierarchische Rekurs über die römischen Dikasterien erschöpft worden ist. Durch den Rekurs an die zweite Sektion können rechtliche Interessen (,interessi legitimi") nicht in Schutz genommen werden. Ausser einem Rechtsbruch erwähnen die "Normen" keine andere Grundlage eines Rekurses, obwohl die Wahl des Wortes ,illegitimitas” in Regimini Nr. 106 wohl andeuten könnte, dass auch andere Grundlagen annehmbar wären, wie das z. B. im ,recours pour excès de pouvoir" der Fall ist. Die „Normen" erwähnen "Notive der Legalität nur im formalen Sinn. Berechtigt zum Einreichen eines Rekurses an die zweite Sektion ist lediglich der Kläger, welcher einen Beschluss verklagt, nicht aber die Behörde, welche den Beschluss gefasst hat. Das Prinzip der Gleichberechtigung im Prozessverfahren würde ein gleiches Recht für dieBeheörde verlangen, deren Beschluss durch eine Dezision des Dikasteriums als rechtswidrig erkannt worden ist. Die "Normen" geben auch keine Antwort auf die Frage, ob der Rechtsschutz einem Laien zusteht, wie dies die postkonziliäre Kirche verlangt, in der die Reorganisation der Jurisdiktion allen Nöten des, Volkes Gottes gerecht werden sollte. 